\title{
APPLYING THE RULE AGAINST PERPETUITIES TO · REMAINDERS AND EXECUTORY INTERESTS ORTHODOX DOCTRINE AND MODERN CASES
}

\author{
Robert J. Lynn and JoHn W. Van Doren*
}

\begin{abstract}
INTRODUCTION
$\mathrm{O}$ VER THE past decade, scholars, legislators, and judges have appraised the common law Rule Against Perpetuities in the light of modern requirements. Consequently and coincidentally the Rule in some jurisdictions has been changed significantly, ${ }^{1}$ modified markedly, ${ }^{2}$ or seemingly abandoned altogether. ${ }^{3}$

Detailed discussions of the reform movement and the changes made are readily accessible elsewhere. ${ }^{4}$ Suffice it to say here that overhauling the Rule is long past due. Some of its characteristics outrage common sense. ${ }^{5}$ Some draftsmen attempting perfectly reasonable dispositions for the care of dependents and successors run afoul of its technicalities. Some courts in handling the Rule show a remarkable lack of imagination. Therefore few will mourn the loss of the administration contingency ${ }^{6}$ and its well-known counterparts.
\end{abstract}

However, in recent commentary there is little emphasis on the Rule as it

* Robert J. Lynn, Professor of Law, The Ohio State University Law School. John W. Van Doren, A.B., Harvard, 1956; LL.B., Yale, 1959; Ford Foundation research grant to Inns of Court 1959-60.

1 The "wait and see" test for validity of future interests under the Rule was adopted by legislation enacted in Pennsylvania in 1947 and in Vermont in 1957. Pa. Stat. ANN. tit. 20, § 301.4 (1950); VT. StaT. ANN. tit. 27, § 3501-03 (1959). The Supreme Court of New Hampshire adopted the "wait and see" test in Merchants Nat'l Bank. v. Curtis, 98 N.H. 225, 97 A.2d 207 (1953).

2 Mass. Gen. Laws c. 184A, \$§ 1-6 (1955); Conn. Gen. Stat. tit. 45, $\$ \$ 45-95$ to 45-99 (1958); ME. Rev. Stat. c. 160, \$§ 27-33 (Supp. 1959); Irx. Rev. Stat. c. 30, § 153(a) (Supp. 1959); Ky. Rev. Stat. $\$ 381.220$ (Supp. 1959).

3 IDAHo Code ANN. \$ 55-111 (1957).

1 Schuyler, Should the Rule Against Perpetuities Discard Its Vest? 56 MrcH. L. REv. 683, 887 (1958); Leach, Perpetuities Reform by Legislation: England, 70 Harv. L. Rev. 1411 (1957); Waterbury, Some Further Thoughts on Perpetuities Reform, 42 MnN. L. Rev. 41 (1957); Leach, Perpetuities Legislation, Massachusetts Style, 67 HaRv. L. REv. 1349 (1954); Tudor, Absolute Certainty of Vesting under the Rule Againsi Perpeinities-A Self-Discredited Relic, 34 B.U.I. Rev. 129 (1954); Simes, Is the Rule Against Perpetuities Doomed? 52 Mich. L. Rev. 179 (1953); Leach, Perpetuities in Perspective: Ending the Rule's Reign of Terror, 65 HARV. L. REv. 721 (1952); Bregy, A Defense of Pennsylvania's Statute on Perpetuities, 23 TExr. L.Q. 313 (1950); Phipps, The Pennsylvania Experiment in Perpetuities, 23 Texp. L.Q. 20 (1949).

${ }^{5}$ See Leach, Perpetuities in a Nutshell, 51 Harv. L. REv. 638, 643-45 (1938).

'See Leach, supra note 5, at 644; In re Wood, [1894] $3 \mathrm{Ch} .381$. 
exists in modern cases. Lord Kenyon periodically is put on the rack for his hatchet job in Jee v. Audley. ${ }^{7}$ Not so the upstart judge of Hunt v. Carroll ${ }^{8}$ who denied that an executory interest must become possessory within lives in being and 21 years or fail under the Rule. Unless, then, we assume that generally accepted statements of the Rule are matters of historical interest only, they describe existing decisions (including the more recent), guide the draftsman seeking to extend control over wealth to the limits allowed by law, and tell us what judges faced with the validity or invalidity of a dispositive provision will do in litigation not yet begun. We propose to show that with respect to remainders and executory interests the Rule Against Perpetuities lacks the definitive qualities popularly attributed to it. Beyond that, we attempt to suggest reasons for judicial disregard of the taught formulae for determining the validity of future interests under the Rule.

I

Although Gray's elliptical definition of the Rule has been criticized from time to time, attempts of eminent authorities to improve upon it have not been particularly successful, and it is firmly enshrined in modern cases. Indeed, one of the few consonant characteristics of recent perpetuities cases is the obsequious bow to Gray. That formality having been complied with, courts may indulge in allusions completely irrelevant to the matter for decision; but for whatever comfort it gives, we can state with conviction that the gods hold steady. Gray's statement of the Rule is as follows:

No interest is good unless it must vest, if at all, not later than twenty-one years after some life in being at the creation of the interest. ${ }^{9}$

Not the least of the difficulties encountered in attempting mastery of the Rule as enunciated by Gray is learning by rote to differentiate those interests subject to the Rule from those which are not. For example, reversions and vested remainders, though future interests, are "not subject to a condition precedent" and therefore are not within the scope of the Rule. ${ }^{10}$ On the other hand, shifting and springing uses, executory devises, ${ }^{11}$ and contingent remainders, ${ }^{12}$ whether in real or personal property, are within the scope of the Rule. However, a contingent remainder need only "vest in interest" within the permissible period; a shifting or springing use or executory devise must ordinarily "vest in possession" to escape destruction. ${ }^{13}$

The insubstantiality of the preceding brief, incomplete ${ }^{14}$ description is readily

71 Cox 324, 29 Eng. Rep. 1186 (1787).

8157 S.W.2d 429 (Tex. Civ. App. 1941).

${ }^{9}$ Gray, The Rule Against Perpetuities $\$ 201$ (4th ed. 1942) (hereinafter cited as GraY).
${ }^{10} I d . \S 283$.
${ }^{11} I d \S 317$.
${ }^{12}$ Id. § 286.
1s Id. §114.

${ }^{14}$ For example, no attempt is made in this paper to discuss the possibility of reverter and the right of entry for condition broken. 
demonstrable. First and foremost, it assumes a rational system for classifying interests, although certain types of interests within the scope of the Rule are in fact almost indistinguishable from those which are exempt. ${ }^{15}$ Second, it subsumes under a single label dispositions serving a gamut of purposes from furtherance of community objectives to indulgence of idiosyncrasies. Third, it presupposes a body of case law sufficient to support the classifications assumed. Last, it requires qualification. ${ }^{16}$

Immediately one who is interested in the formulation of a rational Rule asks these questions: by what criteria are interests classified? What are the rules of construction by which we determine whether or not an interest is present, vested or future for purposes of the Rule? What purposes are served by such rules, and have those purposes any relevance to problems arising out of the devolution of wealth from generation to generation, the creation and perpetuation of family dynasties, dead hand control, and striking a balance between the wishes of the dead and the desires of the living? As we examine recent decisions, we shall attempt to show that the rules of construction are in some respects as potent a weapon in the hands of the courts as is the principal doctrine itself, for the fate of many a dispositive instrument has hinged upon construction: the court may accord to the Rule Against Perpetuities only passing reference and use it to administer the coup de grace. Answers to some of the remaining questions will be suggested in part infra; answers to others are beyond the scope of this paper.

\section{II}

Since a remainder which is "vested" (or which makes timely acquisition of that mystical state) is not within the scope of the Rule, a logical first task is analysis of the distinguishing characteristics of vested and contingent remainders. Then, since a higher degree of "vestedness" is supposedly required of the executory interest than is required of the contingent remainder, those two interests should be differentiated. But before reviewing some authoritative expositions of the distinctions among the classes of remainders, it is desirable to get some conception of the degree of dead hand control sought through using such dispositive devices in the future interests hierarchy.

The remainder and the executory interest are both utilized to effect a shift in the enjoyment of wealth from one person to another upon the happening of a future event. Both the ascertainment of the beneficiary of the shifting com-

${ }^{15}$ See Lymn and Ramser, Applying the Rule Against Perpetuities to Functional Equivalents: Copps Chapel and the Woburn Church Revisited, 43 IowA L. REv. 36 (1957). In Knowles v. South County Hosp., 140 A.2d 499 (R.I. 1958), an executory interest that would have been void under the Rule was saved by calling it a right of entry.

${ }^{10}$ For example, to the extent that the destructibility rule with respect to legal contingent remainders in land persists, a legal contingent remainder in land is saved from destruction under the Rule Against Perpetuities if it is certain to vest or to be destroyed within the period of the Rule. 3 Sumes \& Sirth, Future InTERESTS $\$ 1231$ (2d ed. 1956) (hereinafter cited as Snmes \& SinTH). 
munity protection, and the resolution of the event upon which the shift occurs are purportedly of vital importance. At the effective date of the disposition, the beneficiary of the shift may be ascertained or unascertained. Thus, if $A$, an owner in fee simple of land, grants to " $B$ for life, remainder to $C$ and his heirs," the remainderman is presently identifiable. But if the grant is to " $\mathrm{B}$ for life, remainder to the child or children of B who survive B," the ascertainment of the ultimate beneficiaries cannot be made with certainty until the happening of the event (death of B). Although in the first example the donor has parted with his entire interest, he has achieved some dead hand control simply by taking advantage of the future interests structure. In the second example, he increases the degree of control by introducing uncertainty into the identification of the remaindermen, so that we have a shift in enjoyment complicated by uncertainty of beneficiaries.

In both instances the event (death of B) precipitating the change in community protection is certain to happen, though at the effective date of the disposition time of occurrence remains unresolved. A donor may, however, introduce a greater degree of uncertainty into the event. Thus suppose a grant by $A$ to " $B$ and his heirs, but if $C$ marries $D$, then to $C$ and his heirs." Once again $A$ has parted with his entire interest, for it is certain that either $B$ or $C$ will enjoy the wealth from the time of the grant. But by directing a shift in enjoyment upon an event which may never occur (though it must occur, if at all, within a lifetime), A has projected his control beyond the time of disposition. An even more extreme example is to " $B$ and his heirs so long as St. Peter's stands, then to $C$ and his heirs." Uncertainty pervades the gift over: the event may never occur, but even if it does, the beneficiaries may be unknown descendants or successors in interest of C. Such an executory interest falls afoul of the Rule Against Perpetuities. ${ }^{17}$ However, if the shift benefits the grantor or his heirs rather than a stranger, no violation of the Rule occurs. ${ }^{18}$ This inconsistency in the application of community policy on dead hand control has never been satisfactorily justified.

Whatever the verbal form of disposition, rational application of policy on dead hand restraints requires that techniques directed toward like degrees of control be subjected to like bans. If, for example, the contingent remainder and the executory interest are for perpetuities purposes indistinguishable, they should be accorded equivalent treatment under the Rule. If the exemption from the operation of the Rule of the possibility of reverter and the right of entry is indefensible, their identification with the executory interest should be recognized and the exemption should be withdrawn. From the fact that irrationality is explicable on the basis of history, the extrapolation that it is justifiable cannot be made. Consistency requires equal treatment of functional equivalents,

174 Restatement, Property $\$ 370$ (1936).

${ }^{18}$ Id. $\$ 372$. 
and recognizes and prohibits evasion of community policy through the manipulation of verbal formulae and drafting devices.

It is regrettable that the leading exponents of accepted doctrine have abetted the perpetuation of inconsistency simply through reiteration. All too seldom have they emphasized the fact that categorization of claims to community protection cannot fruitfully proceed in a vacuum. However, if their classifications for all purposes prove tenuous, we may assume that a similar deficiency would be apparent if categorization for perpetuities purposes were essayed. With that assumption in mind, we turn to the authorities.

III

Attacks on the hierarchy of future interests within which the Rule operates are not new. A half century ago Kales, after attempting a rationalization of executory interests and remainders, ${ }^{19}$ parodied Doctor and Student in a classic article on vested and contingent remainders which makes for hilarious reading even today. ${ }^{20}$ But Kales' influence was limited. His treatise, like Gray's, was misnamed. ${ }^{21}$ To a generation of law students he is almost unknown.

What did Kales teach? Simply put, that the purported indices to vested and contingent interests are elusive and full of logical inconsistencies. His implication was clear: the guides to decision on any given problem lie elsewhere. What those guides are he did not state in detail, but whether or not one agrees with Kales in every respect, he did succeed in demonstrating the unreliability of the traditional crutch: classification of interests as a prelude to solution.

If authoritiative writings on future interests are substantial evidence of the effects of Kales' teaching, his was a voice crying in the wilderness. Two editions of Gray ${ }^{22}$ and two of Simes ${ }^{23}$ have appeared within the past half century. Even the fourth edition of Gray is cast in the traditional mould; and the second edition of Simes, though hailed as a "completely new work," 24 does not vary significantly from the first. Despite occasional allusions to the fact that doctrinal distinctions are often merely verbal, ${ }^{25}$ and scattered references to the functional equivalence of interests that are usually differentiated, ${ }^{26}$ the emphasis of both

${ }^{19}$ Kales, Contingent Future Interests After a Particular Estate of Freehold, 21 L.Q. Rev. 118 (1905); Kales, Future Interests in Land, 22 L.Q. REv. 250, 383 (1906).

${ }^{20}$ Kales, A Modern Dialogue Between Doctor and Student on the Distinction Between Vested and Contingent Remainders, 24 L.Q. REv. 301 (1908).

${ }^{21}$ Kales, Estates, Future Interests and Illegal Conditions and Restratnts in ILlinoIs (2d ed. 1920).

22 The third edition of GRAY appeared in 1915; the fourth, in 1942 ,

${ }^{23}$ The first edition of Snas appeared in 1936; the second (prepared in collaboration with Professor Allan F. Smith), in 1956.

${ }^{24}$ Sparks, Book Review, 55 Mich. L. REv. 1044 (1957).

${ }^{25}$ E.g., GraY $\$ 110.1$.

${ }^{26}$ E.g., 1 SnIES \& Surth $\$ 242$ n.9. 
Gray and Simes is on tradition. Assuredly the novice gets the notion that there are several kinds of future interests, that it is useful to master the hierarchy, and that it is sinful to depart from it.

What characteristics purportedly distinguish remainders and executory interests? Although limitations of space preclude a detailed exposition of the authoritative analyses, Gray's definition of a vested remainder serves as a point of departure:

A remainder is vested in A., when, throughout its continuance, A., or A. and his heirs, have the right to the immediate possession, whenever and however the preceding freehold estates may determine. A remainder is contingent if, in order for it to come into possession, the fulfilment of some condition precedent other than the determination of the preceding freehold estates is necessary. ${ }^{27}$

The fact that the remainderman may die before he comes into possession will not, we are assured, preclude "vesting." Thus in a limitation to A for life, remainder to $B$ for life, $B$ has a vested remainder even though he may predecease A, for during its continuance (for the lifetime of $B$ ), the remainder to $B$ is ready to come into possession whenever and however, the preceding estate determines. $^{28}$

Obviously, some conception of what distinguishes a condition precedent from a condition subsequent would be useful. Gray offers little help. Rather, in a footnote he admits: "Estates are construed as vested, not only by holding a condition subsequent rather than precedent, but often also by holding that there is no condition at all." ${ }^{29}$ And in a subsequent series of sections rationalizing the result in Egerton v. Massey, ${ }^{30}$ he says:

When an estate is given on a condition, the condition is always both precedent and subsequent; it is precedent as to the estate which is given on the condition, it is subsequent as to the estate which now exists and will continue to exist if the condition is not fulfilled. The vesting of an estate is not affected by the fact that it may be divested by a condition subsequent. ${ }^{31}$

In other words, a condition is an event. If viewed prospectively, it is precedent; if viewed in retrospect, it is subsequent. That would seem to be clear enough; yet one class of cases, Gray says, "presents some difficulty." 32 A limitation to A for life, remainder to B and his heirs, but if B dies before the termination of the particular estate, then to $\mathrm{C}$ and his heirs, would to the "impartial eye" 33 appear to include two contingent remainders, for "if the condition ever affects B's estate at all, it will prevent if from coming into possession. ...", But that is not the view taken by the common law. ${ }^{35} \mathrm{It}$ is a matter of language:

${ }^{27}$ GRAY $\$ 101$.

${ }^{28} I d . \S 102$.

${ }^{29} \mathrm{Id} . \$ 103$ n.1.

${ }^{30} 3$ C.B.N.S. 338, 140 Eng. Rep. 771 (1857).

${ }^{35}$ "Suppose ... a gift to $A$ for life, remainder to $B$, but if $B$ dies before $A$, then to $C$. Courts everywhere would hold $B$ 's interest vested, yet it is arguable not only that it is limited
"11 Gray \& 113.2.

Id. $\$ 104$.

${ }^{33} I d . \$ 105$.

34 Id. $\$ 104$. 
If the conditional element is incorporated into the description of, or into the gift to, the remainder-man, then the remainder is contingent; but if, after words giving a vested interest, a clause is added divesting it, the remainder is vested. ${ }^{36}$

Carey and Schuyler are not so unequivocal:

[Ê]Ven one fully aware of the difficulties attending attempts such as Gray's to formulate broad generalizations is tempted to query how the above quoted distinction between vested and contingent remainders can possibly be made to square with the commonly accepted view that a gift in remainder to $A$ if he reaches a given age, followed by 'a gift over if $A$ dies under that age, is vested. ${ }^{37}$

The determination of whether "the conditional element is incorporated into the description of, or into the gift to, the remainder-man" invokes the rules of construction. Gray in his treatise "does not profess to deal with questions of construction." ${ }^{38}$ This is in striking contrast to the approach of Carey and Schuyler whose two chapters ${ }^{39}$ on vested and contingent interests contain a rather extensive discussion of those rules of construction which are one of the indispensable keys to trying to make any sense out of the vested-contingent dichotomy.

Gray next ${ }^{40}$ proceeds to single out three kinds of vested remainders for special mention: (1) remainders to a class, (2) remainders after an estate tail, and (3) remainders in default of appointment.

We are told that a remainder limited to a class of persons, the number of which may increase.between the time of the creation of the remainder and the termination of the prior estate, is a vested remainder though it is subject to open to let in additional members. For example, if there is a limitation to $\mathrm{A}$ for life, remainder to his children, each child of $\mathrm{A}$, on its birth, has a vested remainder. Gray feels that in this particular situation ${ }^{41}$ the classification of the remainder as vested is "to some extent artificial" because both the number and size of the shares remain uncertain during A's lifetime. The application of the Rule Against Perpetuities brings out this artificiality by invalidating a gift in remainder to a class which has become vested in a living person, if the number of persons who ultimately will constitute the class will not be determined until a remote period. Gray's statement in the text that "in truth" such remainders

to take effect on a 'dubious or uncertain event,' but also that there is 'uncertainty' as to $B$ 's 'right to take the property.' " CAREy \& SchuYLER, ILLINOIS Future INTERESTS § 292 (1941) (hereinafter cited as CAREY \& SCBUYLER).

- ${ }^{36}$ Gray $\$ 108$.

${ }^{37}$ CAREY \& SCHUYLER $\$ 292$. "[T]here is practically no interest which courts have regarded as vested to be divested which could not conveniently be fit into formal and accepted definitions of a contingent remainder." Id. $\$ 298$.

${ }^{38}$ GRAY $\$ 108$ n.2.

${ }^{39}$ CAREy \& Schuyler, chs. 10 and 11.

${ }^{40}$ Gray $\$ 109$.

${ }^{41}$ Id. $\$ 110.1$. 
are contingent is tempered by a footnote inserted in the fourth edition by his son:

It seems ... not so accurate to say that the law as to the application of the Rule against Perpetuities to such remainders shows that they are really contingent, as to say that such remainders are vested, but are treated for purposes of the Rule against Perpetuities as if they were contingent. ${ }^{42}$

Once again Gray's desire for symmetry caused him to twist a classification to make it fit the Rule.

Gray, with little comment, states that a remainder after an estate tail is vested, since it takes effect "whenever and however" the particular estates determine. ${ }^{43}$ This, despite the fact that by a recovery the estate tail and remainders dependent upon it could be barred so that "a remainder after an estate tail was not only postponed until the failure of the issue of the tenant in tail, but also became dependent on the contingency of the tenant in tail not suffering a recovery. ..." [Emphasis supplied.] "The barring . . is considered as in the nature of a condition subsequent. ..."

In a footnote, doubt is expressed that "as an original question" a remainder in default of appointment should be deemed vested. ${ }^{44}$ But the text asserts that such "seems to be settled law everywhere." ${ }^{45}$ Some ten lines of text cover the problem.

Since Gray sets forth but a chapter on characteristics of remainders, it might be hoped that elsewhere in his treatise he attempts a more penetrating analysis of the distinctions, if distinctions there are. A short section in the appendix ${ }^{46}$ entitled "Vested Remainders and the Rule against Perpetuities" is the only other part of his book devoted to the distinguishing attributes of remainders, although, of course, references to them are made passim. ${ }^{47}$

12 Id. $\$ 110.1 \mathrm{n} .1$.

${ }^{13} I d . \$ 111$.

14 Id. $\$ 112.1 \mathrm{n} .1$.

${ }^{45} I d . \S 112.1$.

${ }^{16} I d$. App. M.

17 Simes and Smith devote an entire chapter to distinguishing vested and contingent remainders. Significantly, in the first edition of his work Simes asked:

"Might not a remainder be vested for the purpose of one legal result and not vested for another? Such a situation is entirely conceivable, but it is believed not to exist to any considerable extent with reference to the legal problems suggested [including the application of the Rule against Perpetuities] . . . the tendency of the courts seems to be to maintain rather uniform concepts of vested and contingent remainders and to vary the applicability, not by saying that in the situation in question the remainder is or is not vested, but by saying that the rule in question does not apply to all vested remeainders." [Emphasis supplied.] 1 SnrEs, FUTURE INTERESTS $\$ 64$ (1936).

In the second edition the quotation set out above has been modified to some extent. E.g., "[T]his process [of varying the applicability of a rule] tends to bring the two kinds of interest [vested and contingent remainders] closer together, and, if carried to its ultimate conclusion we would have two names for interests which had identical characteristics." 1 Surres \& Surrtr \$134. But the emphasis remains essentially the same: "The classification tends to be fairly constant. To the lawyer the significance of this tendency lies in the fact that it is possible to predict, with considerable certainty, the classification which will be given to a remainder merely by an examination of the form of the limitation." Ibid. 


\section{IV}

\section{RECENT CASES}

Recent cases involving application of the Rule to remainders and executory interests fall roughly into a half dozen or so more or less recognizable groups.

A sizeable class consists of opinions showing relative familiarity with doctrinal niceties and consequent ease in application of technicality to the disposition questioned. Many cases in this group require careful analysis by the court of complicated provisions in inter vivos trusts and wills, but altogether too many are some evidence of a predisposition on the part of a minority within the bar to raise the perpetuities question whenever the donor attempts to use future interests when disposing of his property. But as long as we permit some degree of dead-hand control over wealth, we are bound to encounter some nuisance cases unless intra-profession discipline becomes unusually strict. In any event, we concede at the outset of our discussion of current opinions that competence in property law exists and is frequently manifest in appellate court discussions of future interests law.

A second class of cases is made up of those in which classification of future interests is attempted along orthodox lines and is achieved with little or no difficulty but in which an alternative classification is permissible. In Beatty v. Miley ${ }^{48}$ for example, the Supreme Court of Oklahoma construed the following language in a deed: "Party of the Second part [the grantee] to hold said land during the time that the relation of husband and wife exists between the Parties hereto and when such relationship ceases ... this property shall go in equal parts to children of the Party of the First Part [the grantor], provided if any of my children should die leaving children of their own, such children would take the interest of my deceased child." Although the grantor had children living at the time of the grant, the court on the basis of precedent ${ }^{49}$ called the gift to the children a contingent remainder inasmuch as it was conditioned upon "the occurrence of a subsequent event which was certain to happen." grandchildren of the grantor (presumably unborn) was not characterized at all..$^{51}$ The terminology adopted is defensible, but several aspects of the case are

18204 Okla. 634, 233 P.2d 269 (1951). The Oklahoma statute on perpetuities is modeled on that of New York. OKna. Srat. ANN. tit. 60, \$§31-39, 172, 237-38 (1949). It is said to be "not very different from the common-law Rule against Perpetuities." Browder, Perpetuilies in Oklahoma, 6 OkIA. L. REv. 1, 25 (1953). The common law Rule may be in force. Phillips v. Chambers, 174 Okla. 407, 411, 51 P.2d 303, $30 \overline{8}$ (1935).

19 Whitten v. Whitten, 203 Okla. 196, 219 P.2d 228 (1950), involved construction of a limitation in remainder to the "heirs of the body" of the life tenant. The court adopted the orthodox contingent remainder construction.

${ }^{50}$ Namely, cessation of the marriage relationship existing between grantor and grantee at the time of the grant.

st The gift to the "Party of the Second part," the husband of the grantor, was called "an estate similar to a life estate." 204 Okla. at 639,233 P.2d at 274. 
worth noting. First, the case cited as controlling precedent is not particularly apt. Although a remainder limited to "children" of the grantor may for some purposes be equated with a remainder limited to "heirs of the body" of a life tenant, the children of the grantor in the Beatty case were ascertainable, in part at least, at the time of the grant. Heirs of the body of a life tenant are not ascertinable until the tenant dies. ${ }^{52}$ Second, an alternative classification of the gift to the children was permissible ${ }^{53}$ and its adoption minimizes the perpetuities prob$1 \mathrm{em} .{ }^{54}$ Third, the gift to the grandchildren was given no attention whatever. ${ }^{55}$ Was the gift to grandchildren thought to be obviously immune to attack under the Rule?

Sands v. Fly $y^{56}$ is representative of a third group of cases in which classification is attempted along orthodox lines and is not achieved. The testatrix devised lands to her son Howard for life, "with remainder . . . upon the death of said Howard ... to his child or children living at the time of his death, but only for the life of such child or children. ... Upon the death of the last surviving child of Howard ... or upon the death of Howard ... (should he die without being survived by a child), then the first tract of land ... shall pass to and be vested in [a specifically designated sister of the testatrix and six specifically designated nephews and nieces of the testatrix], share and share alike, with the child or children of any one or more of them who may not be living at the ... termination of the life estates... to take, per stirpes, the same share ... that it or their parent or parents would have taken if living at that time. If any one or more of said nieces or nephews should not be living at the time of the vesting of said remainder, and should not be survived by a child or children, then his or her share in the remainder shall pass to the other living nieces or nephews, or to their children. ..." A remainder in fee simple in the second tract was devised one-half to an orphanage and one-half to a

\footnotetext{
32 Insofar as the grantor attempted a gift to her clildren, the Oklahoma court read "this property shall go ... to children of the [grantor], provided if any of my children should die leaving children of their own, such children would take the interest of my deceased child" as the equivalent of "this property shall go ... to such of my children as survive the termination of the life estate." The equivalence is logically permissible, and therefore likening the former limitation to a gift to "heirs of the body" of a life tenant is defensible.

53 It was "vested subject to divestment" by executory interests in grandchildren of the grantor. Nothing precludes characterizing a gift in remainder to the "heirs of the body" of a living person as "vested subject to divestment" (or, better yet, "vested subject to defeasance") if there are persons in being at the time of the gift who would qualify as takers were the ancestor to die. Characterization did not, however, develop along those lines. See Moore v. Littel, 41 N.Y. 66 (1869) for a demonstration of the difficulties presumed to be attendant upon attempts to escape from tradition.

51 But its adoption does not eliminate perpetuities difficulties. Leach, The Rule Against Perpetuities and Gifts to Classes, 51 HARv. L. REv. 1329 (1938).

${ }^{55}$ If a child of the grantor died during the duration of the life estate, survived by a child or children, would such grandchildren of the grantor have to survive the life tenant (or be alive at the termination of the life interest however terminated) in order to take?
}

ss 200 Tenn. 414, 292 S.W.2d 706 (1956). 
specifically designated niece of the testatrix "provided she should be then living, and if not then her share ... shall go ... to her mother ... and her two sisters... share and share alike."

Howard, individually and as executor of the estate, contended that "certain devises ... to named remaindermen in fee simple" as well as the remainders for life to his own children were contingent and void under the Rule. A guardian ad litem for the children acquiesced in the latter contention. Howard conceded that the gift to the orphanage was " $a$ fee simple estate, postponed only in possession." The Supreme Court of Tennessee, after making the usual allusion to effectuating the intention of the testator "if it does not contravene some rule of property, or ... public policy," quoted the definitions of contingent remainders of Tiffany and Gray and concluded that "while the "conditional element' was incorporated in the gift to the remaindermen [following the particular estates to Howard's children], it definitely and conclusively appears that this condition was satisfied at the time of the testatrix's death, all children of Howard . . . being alive at that time." However, a few paragraphs later we find that "the number of children was not important, or that some might be born after the death of the testatrix. The legal effect of the ... language was to devise the fee simple estate in the named remaindermen, the same being vested in interest with the right of possession postponed. ..." And finally, "the remaindermen ... were ascertained when the will took effect. While the will provided that should one of them die without children surviving, his or her share should go to the survivors, this in no way postponed the vesting. ... It was in effect a devise of a remainder in the alternative. ... " The life interests given Howard's children were vested subject to open.

Several aspects of the opinion are of interest. First, the court never explicitly examined the gift of a remainder in fee simple to a specifically designated niece of the testatrix "provided she should be ... living" at the death of the last surviving child of Howard (or at the death of Howard should he die without a child surviving him). If such a gift is "vested," what language of condition is required to make it contingent? And what of the gift in the alternative: "and [if the specifically designated niece be] not [living at such time] then her share ... shall go ... to her mother... and her two sisters ... share and share alike"? Second, if a nephew or niece specifically designated as remainderman of the first tract failed to survive the termination of the life interests given Howard's children, it is at least arguable that the gift given the child or children of such nephew or niece was conditioned upon such child or children's surviving the termination of the life interests given Howard's children. If so, the gift to such child or children of such nephew or niece would be bad under the Rule. If a condition of survivorship were not implied, the gift to such child or children would be good, for irrespective of classification it would be transformed into a vested remainder in a child or children of nephews and nieces on the death of such nephew or niece during continuance of the life interests, survived by such 
a child or children. Sands $v$. Fly reaches an acceptable result without careful analysis of the ultimate interests.

Cases in a fourth class consist of opinions in which partial classification of interests is attempted along orthodox lines and is achieved with little or no difficulty. In Lowe v. Rice, ${ }^{57}$ the testator, survived by his widow, three children, and six minor grandchildren, devised land in trust for his widow for life and "in the event of her death the remainder interest is hereby devised as tenants in common to all my Grandchildren, six now in number [naming them], and any other Grandchildren hereafter born to my three children." The life tenant died. In a proceeding to obtain court approval of a proposed exchange of land in which minor grandchildren of the testator were tenants in common, a party contended that grandchildren born after the death of the life tenant did not share in the gift of the fee, and apparently argued that if included, the gift in remainder violated the Rule Against Perpetuities. The Court of Appeals of Tennessee did not agree with either contention, stating with regard to the first that "all of the grandchildren ... living at the [death of the life tenant] have a vested estate... . which vested estate will ... open up to include any other grandchildren who may be born hereafter," and with regard to the second that "clearly, the devise involved ... does not violate the rule against perpetuities. ..." No further analysis of the future interests was attempted or, apparently, thought necessary.

Fobringer v. Romano $0^{58}$ is an example of opinions in which classification of interests is not attempted. The testator devised his residuary estate in trust, the income to be paid for a thirty-five year period to his five surviving children and a son-in-law, husband of a deceased child. A provision of the will directed that upon the death of an income beneficiary "his or her Trust Fund pass to his or her children ... provides [sic] however that the Trust be continued ... [for thirty-five years] only with the beneficiaries being changed." At the end of the thirty-five year period, principal was to be distributed. In a proceeding for construction, the will was attacked for violating the Rule Against Perpetuities. The Superior Court of New Jersey, Chancery Division, without classifying future interests, ${ }^{59}$ was able to determine that no transgression of the Rule had

5740 Tenn. App. 298, 291 S.W.2d 287 (1956).

${ }^{58} 7$ N.J. Super. 432, 71 A.2d 660 (1950). On appeal, the judgment of the superior court was affirmed by the appellate division. Forbringer v. Romano, 10 N.J. Super. 175, 76 A.2d 825 (1950).

${ }^{59}$ In Adams v. Vidal, 60 So.2d 545 (Fla. 1952), the testator created a testamentary trust for the benefit of two minor nephews and a minor niece. In a proceeding for construction of the instrument it was contended that the following illustrative language in the will violated the Rule:

"In the event Milton ... Irma ... and Leonard ... are each living at the time Leonard $\ldots$ arrives at the age of twenty-one ... and providing that they have each made their home $\ldots$ at the old home place ... I. . . devise ... said property ... to [them] in fee simple ... share and share alike, and to the survivor of them, subject to conditions...."

"f. In the event of the death of Milton ... before marriage, or in the event of his marriage 
occurred. The five children and the son-in-law took a "vested" interest in the principal of the trust, possession only being postponed for thirty-five years. "If any [such] beneficiary fails to survive such thirty-five-year period, his or her children . . . receive the principal at the appointed time, in the meantime enjoying the income." That possession of a grandchild's interest in principal might be postponed beyond lives in being and twenty-one years was apparently not deemed controlling: "The rule is directed solely against the unlawful postponement of the vesting of estates, and is not applicable to their possession or enjoyment." If the interests of grandchildren are executory interests, what of the orthodox statemen $t^{60}$ that executory interests do not have the capacity to vest in interest before they vest in possession? ${ }^{61}$

Finch v. Honeycutit ${ }^{62}$ is a more recent manifestation of the cavalier disregard for careful analysis of interests. The testator, who died in 1956 survived by his widow and three minor children under ten years of age, devised half of his estate in trust for the three children "until \& when the year 1980-then $\frac{1}{3}$ of residue be paid to my children or his or her children if any child of mine should die before reaching the year 1980. Trustee may have two years to pay said $\frac{1}{3}$ of estate to said children of [or] their heirs $-\frac{x}{2}$ of balance ... shall be distributed in the year 1992 on the same conditions. . . . The balance . . . to be distributed in the year 2005. ..." In a declaratory judgment proceeding the guardian ad

and his subsequent demise leaving no widow, children or descendants of children him surviving, then the entire interest held by Milton ... shall vest in Irma ... and Leonard ... equally, or in the survivor of them, and if [both] have predeceased Milton ... then the entire interest held by him shall vest in Adolphe . . . and Albert . . . if living, and if deceased, then to his or their heir or heirs."

The Supreme Court of Florida refused to give an indefinite failure of issue construction to the words "descendants of children him [or her] surviving" and were "unable to envisage the possibility of a ... vesting of the subject property in fee simple at a time beyond lives in being and twenty-one years. ..." The two nephews and the niece took a fee simple subject to divestment by a future interest never explicitly classified, though the expression "executory limitation" does appear in that portion of the opinion dealing with failure of issue.

In Heilig v. Daniel, 203 Ore. 123, 275 P.2d 854 (1954), the testatrix created a testamentary trust for the benefit of her daughter. The trustees were directed to use both principal and income, as they deemed necessary, for the proper support of the beneficiary during her lifetime, and "upon [her] death . . . then one-half [the corpus] . . . to the heirs of her body or the survivors of them share and share alike, ... If no survivors of the heirs of the body . . . my estate to be divided . . . equally and share and share alike among the blood relations of my deceased mother and myself." To a contention that the testatrix intended the trust to continue indefinitely for the benefit of the heirs of the body of the daughter, the Supreme Court of Oregon replied that the daughter was a person in being at the time the [future] interest was created. "If then, the estate vested before or immediately after the death of [the daughter], there could be no violation of the rule against perpetuities." In disposing of the perpetuities problem, the court made no classification of interests.

${ }^{60}$ Leach, Perpetuities in a Nutshell, 51 Harv. L. Rev. 638, 648 (1938).

${ }^{81}$ Carey and Schuyler reject the orthodox view. CAREY \& SCHUYLer $\$ 474 ;$ id. $\$ 480$ (Cum. Supp. 1954). Harris v. France, 33 Tenn. App. 333, 232 S.W. $2 d 64$ (1950), discussed in note 67 infra, is comparable to Forbringer v. Romano.

62246 N.C. 91,97 S.E.2d 478 (1957). 
litem for the three minor children contended that the terms of the will violated the Rule Against Perpetuities. The Supreme Court of North Carolina detected no violation of the Rule:

The gift ... to the children vested in interest... immediately upon the death of the testator, although the full enjoyment is postponed....

Even though the postponements here ultimately invade the Twenty-first Century, reference to the ages of the children indicates that the postponements are within the life or lives of the beneficiaries in being and twenty-one years and ten lunar months thereafter....

The opinion not only fails to characterize the gift to unborn grandchildren of the testator but also fails to recognize that any such gift exists. Yet under the admittedly ambiguous language of the instrument it seems reasonably clear that if a child of the testator died before 1980 survived by a child or children alive in 1980, such grandchild or grandchildren of the testator would take the share his or their parent would have taken had the parent survived to the time of distribution. ${ }^{63}$

In a sixth group of cases orthodox doctrine is rejected. A Texas court in Hunt v. Carroll, ${ }^{64}$ with an eye on the practical purposes served by restraints rather than upon the niceties of feudal classifications, brushed aside a contention that an executory devise cannot vest in interest before vesting in possession and upheld a disposition for the care of a daughter and grandchildren of the testator. The will expressed love for the daughter and a desire to protect her "against future contingencies and adversities." The testator had disapproved of his daughter's marriage, and so long as the marriage continued, no part of the estate or income was to be paid to her except in case of serious medical need, but if she became a widow within ten years and did not remarry her present husband, she was to receive $\$ 250$ per month; and if still living at the end of twenty years, she was to receive the entire estate. If she died before the end of twenty years, leaving a child or children surviving her, such child after completing his education under the care and discretion of the executor was to receive $\$ 50$ per month as long as engaged in a legitimate occupation until he attained 30 , when he was to receive his proportionate part of the estate. Should such child "die without issue" prior to attaining 30 , his share was to go to his surviving brothers and sisters, if any, and if none, to the brothers and sisters of the testator or their heirs. The Texas Court of Civil Appeals characterized the interests of the daughter's children "equitable executory" devises. "[I]n Texas equitable executory devises can vest prior to the termination of the

${ }^{63}$ It is not clear that a condition of survivorship is attached to the gift to grandchildren. If it is (that is, if the language "to said children of [or] their heirs" means clitld of the testator alive in 1980 or that person who is such child's heir at that time) there is a possible violation of the Rule. For example, all of the testator's children might die immediately after his death. More than twenty-one years would then elapse between the time such children die and the year of distribution-1980. Only then - at a remote time-would the identity of the "heirs" be fixed.

${ }^{61} 157$ S.W.2d 429 (Tex. Civ. App. 1941). 
trust. So, an estate, whether a remainder or an executory devise or interest is vested within the Rule when it is vested in interest; it can vest in interest before it vests in possession; the requirements of the Rule in this respect are complied with when a future estate or interest becomes vested in interest, regardless of when it becomes vested in possession."

\section{$\mathrm{V}$}

What is the explanation for non-classification of interests, incomplete classification, improper classification and the indefinite variations on all three practices? Any attempt at rationalization amounts, for the most part, to a guess. The following, of sundry degrees of plausibility and persuasiveness, are offered in lieu of more exact information not presently available.

One group of cases might be termed "administrative expediency" cases. The questioned interests in the disposition before the court may be sufficiently like those encountered in prior cases to warrant validating or invalidating gifts without pausing to classify. In Singer v. Singer ${ }^{65}$ the testator devised his property in trust for the benefit of his "children or their substitutes" and directed that his estate be kept intact for ten years after his death. Net income during the ten year period was to be divided among his six "children or their respective substitutes." At the expiration of the ten year period and at such time as the trustees deemed to be "within good business judgment" there was to be distribution of the estate to the six children if alive, and if dead "leaving a child or children or descendants thereof surviving them, then that portion ... which has not been distributed but which would go to such child or children if they were alive ... shall pass to and vest in their respective natural child or children. ..." A son of the testator who had survived the testator for four years died survived by an only son and a second wife. A dispute between the son and the widow of the beneficiary under the will required construction. The widow contended that distribution of the estate at such time deemed to be "within good business judgment" by the trustees might be deferred to a time beyond that allowed by the Rule Against Perpetuities. The Supreme Court of Texas dismissed that notion in a single line: "The contention is without merit." Citing $R u s t$ v. Rust, ${ }^{\text {te }}$ the court held that the son of the testator took a vested interest in the fee ("a conditional or defeasible fee") on the death of his parent. The interests of grandchildren and more remote descendants of the testator are nowhere characterized in the opinion, although incidental reference is made to a grandson as "remainderman."

Rust v. Rust, cited as applicable precedent in the Singer case, involved construction of a testamentary gift in trust for the minor daughter of the testator to "be held . . . until 1967, [when] the trust shall terminate and the property ... shall vest in fee simple in my daughter . . free of any restrictions. . . "If

Es 150 Tex. 115, 237 S.W.2d 600 (1951).

66147 Tex. 181, 211 S.W.2d 262 (1948). 
the daughter died before 1967 survived by issue of her body, such issue were to "become the beneficiary or beneficiaries of this trust and upon the date of its termination the fee simple title . . . shall vest . . . in such issue of her body then surviving." In default of such issue, the property on the death of the daughter before 1967 was to go to the then living brothers and sister of the testator, or their child or children per stirpes. The trustees were given power to use income or corpus in their discretion for the support and education of the daughter or "any child ... of hers" who might become a beneficiary. The testator had died in 1942. The Texas Court of Civil Appeals stated that the determination of whether or not the gift to the daughter violated the Rule Against Perpetuities depended on whether her surviving until 1946 (a date 21 years prior to termination of the trust) constituted a condition precedent to the vesting of title in her, or whether her dying before that time constituted a condition subsequent divesting a title in her which had vested at her father's death. After consulting the Restatement of Property for appropriate canons, the court concluded that she took a fee "immediately upon the death of her father, defeasible upon the condition subsequent of her death prior to . . 1967...." The gift in default of issue was characterized as made to "named contingent remaindermen" and found innocuous. The gift to issue of the body of the daughter proved more troublesome. Did the language of the instrument require that such issue [construed by the court to mean "children"] survive to the time the trust terminated -1967-in order to take? The court thought not. They took a "vested remainder upon the death of the daughter prior to ... 1967, leaving bodily issue. ..." However, if the court were mistaken and the gift to the issue was void, "the other provisions of the will would not thereby be affected."

If the daughter in the Rust case took a defeasible fee, clearly the gifts over are not remainders, for remainders generally speaking, do not "divest." If we review the Rust case from the standpoint of technical validity of the interests, given the court's construction, it is acceptable. It is hardly a good lesson in orthodox doctrine. ${ }^{67}$

${ }^{67}$ In Fuller v. Hedgpeth, 239 N.C. 370,80 S.E.2d 18 (1954), the provisions of a testamentary trust are set out in some detail. After briefly summarizing in a general way the tenor of the dispositions made, the Supreme Court of North Carolina held that the Rule Against Perpetuities was not violated, stating: "The controlling factor in the application of the rule ... is the time when a future interest vests, rather than the time when it comes into enjoyment." No classification of interests was attempted.

In Gardner v. Dillard, 258 S.W.2d 93 (Tex. Civ. App. 1953), the testators devised land to "Edcut Ward Dillard for his life only ... but he shall have no power to sell or dispose of same, and after his death we hereby give ... the said . . . land to the lawful heirs of said Edcut ... in fee simple. ..." The Texas Court of Civil Appeals found no violation of the perpetuities rule. The gift to the heirs was referred to simply as "the remainder."

In Harris v. France, 33 Tenn. App. 333, 232 S.W.2d 64 (1950), the testator made the following devise: "I hereby will . . . in trust ... all of my real estate . . for the sole use ... of the children of my said nieces and nephews above named ... the profits to be divided among [them]. ... And provided further, that this trust shall continue until the youngest child ... reaches the age of thirty ... whether . . . born before or after my death. . . . Provided further that ... my land ... is to be divided ... among the children...." The will individually 
A variation on the appeal to precedent is the practice of honoring the opinion of the court or courts below, with whatever classification or lack thereof the latter sees fit to indulge. Crockett $v$. Scott $t^{68}$ is a case in point. The testatrix gave her residuary estate, in substance, to her sister for life, then to her sister's children for their lives, "and after their death to their children if they have any and if they have none to their next of kin." The testatrix had died in 1880, and at that time her sister was 50 years old and had six children. The Chancellor below having presumed that the first life tenant was capable of having further issue, the Supreme Court of Tennessee acquiesced in a finding that the interests called remainders in fee by the Chancellor violated the Rule. The only characterization of ultimate interests by the Supreme Court was by implication: "We will not attempt to trace the development of the rule [against perpetuities] because the law books are full of it. . . We will say only that the limit, under the rule, for the creation of executory interests to commence, is 'within the period of a life or lives in being and 21 years....'"

Miller v. Bank ${ }^{69}$ also falls within this group of cases. The testator gave his net estate to his widow for life, and "at the death of my wife ... I direct that all the income, derived from any source, be equally divided among my surviving heirs." The testator was survived by his widow and two children. Following the death of the life tenant, the two children, joining the executor in a proceeding for construction, contended that the will violated the Rule AgainstPerpetuities. The Court of Appeals of Virginia stated that it agreed with the findings of the court below that there was no violation of the Rule and with its classification of the interest following the life estate as a vested remainder in the two children. The characterization adopted is defensible, though it requires treating "surviving" as superfluous. More significant, perhaps, is the fact that careful analysis of the future interest is not required since any contingent remainder would vest at the death of the life tenant-a life in being at the time the interest was created.

"Technical competency" cases bulk large among modern perpetuities cases. Sands v. $F l y^{70}$ is symptomatic of inability to apply the traditional future interests formulae to the classification problem presented. At the other end of the spectrum, a court may regard the solution to classification as being so obvious as to require no mention in the opinion. Rose v. Rose $e^{7 y}$ probably falls within

identified the nieces and nephews of the testator. The Court of Appeals of Tennessee held that gifts of corpus "vested" at the latest at the death of the survivor of the named nieces and nephews and that therefore the Rule Against Perpetuities was not violated. Apart from classifying gifts to afterborn children (grandnieces and grandnephews) as "executory devises," the court did not analyze the gifts.

68199 Tenn. 90, 284 S.W.2d 289 (1955).

69191 Va. 297, 60 S.E.2d 868 (1950).

${ }^{70} 200$ Tenn. 414, 292 S.W.2d 706 (1956).

7191 Va. 171, 60 S.E.2d 45 (1950). 
this group of cases. The grantor and his wife executed a deed of land to their son Otto "and his children and their children." At the time of the grant, Otto had four living children but no grandchildren, though eleven grandchildren were born to him thereafter. After the lapse of twenty-five years, Otto and his wife and three of their children conveyed their interests in the land to Otto's fourth child, who then claimed a fee simple as against Otto's eleven grandchildren. The Supreme Court of Virginia, after noting that the grantor meant to "restrict the inheritance ... to the lineal descendants of Otto," presumed that the word "children" included after-born children, and that being so, the attempted "future interest" in great-grandchildren of the grantor was void under the Rule.

The Supreme Court of Kansas in In re Davis' Estate ${ }^{72}$ considered the validity under the Rule of a provision in a postnuptial agreement between Davis and his wife, stating that in the absence of a sale of land before Davis' death 'his interest in said land will pass to Ida Georgia Davis [the wife] for her use and that she shall have the net income therefrom so long as the said Ida ... shall live or until she shall remarry ... that upon her death or remarriage, the remainder ... shall pass in fee simple to the bodily heirs of Herbert [the husband]...." The court disposed of the perpetuities argument in a single line: "Resort to the provisions of the ... agreement ... makes it crystal clear that every provision ... was to become effective within 'lives in being." " Classification of the future interest given the bodily heirs of Herbert was apparently thought to be superfluous.

In Federal Trust Co. v. Walsh ${ }^{73}$ the testator left his residuary estate in trust for his widow for life and upon her death he directed that his estate be divided "into as many shares as the number of my children, the child or children of any deceased child to take the share his ... parent would have ... if living.... The share of any deceased child who left child or children may be paid over ... at any time between the death of my wife and the date when the youngest child reaches the age of thirty...." The opinion states that children of the testator asserted that "the remainder over to the grandchildren" was void for remoteness inasmuch as the ultimate number in the class could not be determined until the youngest grandchild attained thirty and such grandchild might be born after the death of the testator. The Superior Court of New Jersey did not agree that the gift to grandchildren was conditioned on their surviving to the time that the youngest reached thirty. "[V]esting in the grandchildren occurs immediately upon the death of the parent in the lifetime of the life tenant." Children of the testator had a "vested interest in ... remainder, which interest $\ldots$ is subject to divestment upon their death in the lifetime of the life tenant leaving a child or children surviving." It is not clear that the court adopted

72171 Kan. 605, 237 P.2d 396 (1951).

${ }^{73} 20$ N.J. Super. 542, 90 A.2d 119 (1952). 
the characterization of the gift to grandchildren advanced by the children. It is clear that at no point in the opinion is the gift given its traditional classification of executory interest.

On occasion courts simply make mistakes. Two cases decided at about the same time involved substantially the same initial problem, namely, appropriate characterization of a gift of the unexpended portion of an annuity upon the death of the first annuitant. In Beulens Estate ${ }^{74}$ the testatrix provided for the purchase of an annuity for Isabelle and directed that should Isabelle die prior to the time the annuity was paid in full to her, "then whatever remains of the above bequest shall go to her daughter, Marilyn ... provided the said Marilyn ... has reached the age of forty...." A Pennsylvania Orphans' Court called the gift to Marilyn a contingent remainder which violated the Rule Against Perpetuities "because the remainder only vests if Isabelle ... should 'die prior to the time the above annuity is paid in full to her,' and then only 'provided the said Marilyn . . . has reached the age of forty years.' It is, of course, entirely possible that Isabelle ... might die within the next ten years, and it would in that event be more than twenty-one years before the contingent remainder could vest, since Marilyn ... was between nine and ten years of age at the time of testatrix's death."

Regardless of classification, the gift to Marilyn was good. If Marilyn were required to attain forty at the time of the death of Isabelle in order to take, the gift would take effect or fail, as the case might be, at the death of Isabelle, a life in being at the death of the testatrix. If Marilyn were merely required to attain forty in order to take (irrespective of whether she attained that age before or after the death of Isabelle), she would attain such age or not, as the case might be, within her own lifetime, a life in being at the death of the testatrix.

In Tiehen v. Hebenstreit ${ }^{75}$ the testatrix devised property in trust for the benefit of two children and a grandchild, son of a deceased daughter of the testatrix. The trustee was directed to pay $\$ 1200$ annually to each child until onethird of the net estate had been paid to him, and if a child died before having received one-third of the net estate, "then in that event the residue thereof shall be paid to ... [his] children ... or the survivor of them ... in the same manner and in the same amount ... [and] if all of ... [his] children ... shall die before the full amount ... is distributed to them then ... the balance, if any, ... shall be paid to [a designated church]. ..." The two children of the testatrix contended that the gifts to them violated the Rule Against Perpetuities inasmuch as both might have more children who would come within the terms of the will. The Supreme Court of Nebraska did not agree. Children, given its "ordinary meaning," referred to grandchildren of the testatrix in being at her death. The "remainders" given the children and the church "vested" at the death of the testatrix and were valid.

7426 Erie County L.J. 309 (Pa. Orph. Ct. 1944).

76152 Nebr. 753, 42 N.W.2d 802 (1950). 
Even if we agree that the gift to grandchildren did not include afterborn grandchildren, and even if we agree that the Rule was not violated, it is diffcult under orthodox doctrine to accept the classification of future interests advanced in Buelens Estate and the Tiehen case. Inasmuch as the future interests in both cases were conditioned on the failure to exhaust funds during the lives of the primary beneficiaries, they were subject to a "condition precedent" if that expression has any content at all. And unless the word "remainder" has recaptured the classic etymology of "left," the future interests were executory interests, not contingent remainders. ${ }^{76}$ These cases are not instances of a devise to $A$ for life, remainder to $B$ and his heirs at the death of $A$. Rather, they are comparable to a devise to B and his heirs at the death of $A .{ }^{77}$

Of course as the Supreme Court of Illinois pointed out in Spicer v. Moss, ${ }^{78}$ one mistake made in applying a rule doesn't change the law unless the mistake is adhered to. In the perpetuities field, as elsewhere, it is obviously difficult in some cases to determine whether or not a change in the law is being made covertly.

Cases which analytically may or may not be part of the foregoing group are those in which courts generalize about "interests," "future interests," "remainders" or some such like word or group of words. Conceivably such courts are consciously assimilating interests of various kinds which are traditionally differentiated. Perhaps the unsatisfactory opinion in Tolman v. Reeve ${ }^{79}$ is explainable on such a basis. In that case the testatrix left a house and furnishings in trust to be maintained in the first instance as a home for her two sons, Justus and Bryant. She then expressed a "wish" that if Justus died leaving a wife or children, "each or all of his family may live in the Old Homestead as long as they may desire." In the event her sons died without lawful issue and "after the death of all of the children of my said sons before they or any of them shall have attained the age of twenty-one ... and after the death or remarriage of the widow of my said son Justus ... then . . . I give . . . said Old Homestead to my niece Blanche... and to her heirs in fee simple," but if Blanche be not then living, to the Daughters of the American Revolution. A contention was made that Justus might marry a woman not in being at the death of the testatrix and that the vesting of the fee was conditioned upon the death or remarriage of an unborn person. The Supreme Court of Illinois, in rejecting the notion that the Rule Against Perpetuities had been violated, first

${ }^{\pi 6}$ In Ball v. Ball, 136 W.Va. 852, 69 S.E.2d 55 (1952), the testator created a trust of all his property to pay annuities to designated beneficiaries. When all such beneficiaries were dead or the funds exhausted, "closing up" of the estate was to occur and "if any funds remain" they were to be "disbursed equally among ... [the testator's] nearest of kin." The Supreme Court of West Virginia held that the nearest of kin (determined at the death of the last of the annuitants) had a contingent remainder which did not violate the Rule.

77 But see 1 Stares \& Sactr $§ 150$.

78409 Ill. 343,100 N.E.2d 761 (1951).

${ }^{79} 393$ Ill. 272, 65 N.E.2d 815 (1946). 
pointed out that the widow of Justus, if any, acquired no estate, but merely a right to occupy the Old Homestead as long as she remained Justus': widow. "Vesting of the title in fee simple is ... not postponed by the provision for the possible widow.... The latest possible moment of vesting is, consequently, the death of either Justus or Bryant, or the death of all their children before any of them reach ... twenty-one years." The court either characterized the interest of Blanche as a "contingent remainder" or simply reported a classification advanced by one of the parties. Two statements by the court refer only to "the remainder." The interest given the Daughters of the American Revolution was not explicitly characterized..$^{80}$

Proper characterization of the gift over in the alternative is, according to orthodox doctrine, of vital importance. If the interest of Blanche is called a vested remainder subject to divestment by the executory interest given the Daughters of the American Revolution, the latter is bad under the Rule for possession might be postponed during the lifetime of a person unborn at the death of the testatrix, namely, Justus' widow. ${ }^{81}$

A third broad category of cases might appropriately be termed "policy" cases. If a flagrant violation of the Rule is specifically pointed out by counsel, the transgressing interest is usually stricken down by the courts. ${ }^{82}$ But if a

${ }^{80}$ In Griffin v. Springer, 244 N.C. 95,92 S.E.2d 682 (1956), the grantor by deed gave a life estate to one Nelme and "at his death [the property was] to be divided to the parties of the third part [two designated daughters of Nelme named Mary and Nona] equally, and to the children of the said Mary and Nona Nelme, respectively, at their death." After the death of the father of Mary and Nona, the latter, joined by their respective husbands, contracted to convey a portion of the land covered by the deed. In an action to determine whether or not Mary and Nona could together convey a fee simple, the nature and validity of the interests given their children came into question. Neither sister had children at the effective date of the deed, but Mary had four children living at the time the sisters contracted to convey. The Supreme Court of North Carolina discussed the interests given the children of the sisters at three points in the opinion. In two instances the court reiterated generally accepted statements about contingent remainders and vested remainders subject to open, but it used generalized language when explicitly settling the perpetuities question: "The grant of the future interest in the land 'to the children of the said Mary and Nona Nelme respectively at their deaths,' means that the future interests of Mary Nelme's children must vest during her life, and the future interests of Nona Nelme's children, if any, must vest during her life."

${ }^{81}$ An error in the opinion has already been pointed out by Carey and Schuyler: "The nature of [the widow's] interest in this respect is wholly immaterial upon the perpetuity question because a life estate to a widow terminable upon her death or remarriage has never been held to preclude the vesting of a future interest after it." CAREY \& ScHoYLer $\$ 480$ (Cum. Supp. 1954). Perusal of the opinion does not make clear the method by which the perpetuities problem was raised. Presumably it was argued that the gift to Blanche was void because conditioned upon her surviving the death or remarriage of an unborn persom. But irrespective of the classification of the gift made to Blanche, the interest given her would become possessory or not, as the case might be, within her own lifetime-a life in being at the death of the testatrix. If Blanche died before the resolution of the contingencies attached to the gift to her, the gift to the Daughters of the American Revolution would become indefeasibly vested or fail, as the case might be, within the lives of Justus and Bryant and 21 years.

${ }^{82} \mathrm{~A}$ gift to great-grandchildren of the settlor fell under the Rule in Wright v. Renehan, 10 N.J. Super. 363,76 A.2d 705 (1950). Although the opinion contains little analysis of inter- 
violation appears on the whole to be relatively innocuous, the transgressing interest may be caught up by the encompassing adjective "vested" and saved. Clayton v. Burch ${ }^{83}$ is illustrative of the former type of case. There the testator devised realty to his wife for life during widowhood "and at hear deth ... or marrig then ... to My Grand Sound John W. Clayton . . . to have and to hold his life time, thence to his Body ars if he has Eny and if not then if my Grand Sound Silus Daynel Clayton if he a living but if J. W. Clayton Shold hav a body hir it Shall go to them down to the Tenth Jenerration and shal never be Sold for Eney pupus what Sover...." Following the deaths of the widow of the testator and of John W. Clayton, children of the latter, claiming the land as tenants in common, sued one claiming under a mortgage deed executed by their father and his second wife. After finding that the Rule in Shelley's Case did not apply and that the direct restraint on alienation was void, the Supreme Court of North Carolina disposed of the perpetuities problem in a single line: "The words in the will the land 'Shall go to them down to the Tenth Jenerration' are void, being within the rule against perpetuities." 84

Trumlin v. Troy Bank \& Trust Co. ${ }^{85}$ exemplifies the latter type of case. The testator left a $\$ 3,000,000$ residuary estate to the bank in trust and provided that "at the expiration of twenty years after my death and after all bequests herein shall have been paid as herein directed," the trustee should pay income to an educational association appointed by parties other than the trustee to be used for educational purposes. Heirs ${ }^{86}$ of the testator contended that the gift to charity was a springing use which might vest remotely because the appoint-

ests, there is a fairly clear characterization of the gift to great-grandchildren as a contingent remainder. Although one grandchild of the settlor was in existence at the time the inter vivos trust was created, the possible application of the rule of Cattlin v. Brown, 11 Hare 372, 68 Eng. Rep. 1318 (Ch. 1853), to the gift to great-grandchildren was not discussed-and perhaps not argued. (Under the rule of the Cattlin case, an otherwise remote gift may be saved if the parent of the great-grandchild was alive at the effective date of the instrument.)

83239 N.C. 386,80 S.E.2d 29 (1954).

81 The gift to the 'body ars' of the 'body ars' of John, being to unborn children of unborn children, was clearly bad.

$85258 \mathrm{Ala}$. 238, 61 So.2d 817 (1952). Alabama has a statute on perpetuities applicable only to real estate, ArA. CoDE ANN. tit. 47, $\$ 16$ (1941), but it states that the common law Rule is in force with respect to both realty and personalty.

86 The analysis made by counsel for the heirs is not set forth at length in any of the opinions, but it is summarized in $258 \mathrm{Ala}$. at 275 and 61 So.2d at 853 as follows:

"Counsel for appellants devote a considerable part of their brief . . . in support of the argument that the equitable interest in the school trust could not vest immediately upon the death of the testator because the interest ... is not a remainder, but a springing use. . . . This assertion is based on the following construction placed on the will: 'The prior estates might terminate at any time by the death of the individuals, but the termination of the prior estate would not eo instante convert the ulterior estate into a present interest.' Counsel argue: 'It is a springing use, because it is limited to be enjoyed upon the happening of events entirely independent of the expiration of the prior interest. There is a possibility of a gap. In fact there is the certainty of a gap." " 
ment of the administrators might occur more than one year after the duration of the 20 year period designated by the testator. Majority, concurring, and dissenting opinions in the case run to some thirty-seven pages. In none of them does classification of the future interest go beyond the haphazard. The majority opinion refers to the gift of income as "fixed and vested and not contingent." One of the concurring justices ultimately contented himself with the statement that "the fact that testator provided that his trustee pay the income ... to the Association after it is formed is not inconsistent with the construction that the equitable estate vested in the beneficiary at time of testator's death." A dissenting opinion stated that "futurity is annexed to the substance of the gift and ... the remainder, rather than being vested, was contingent...." The other opinion dissenting to the rehearing characterized the "future" "equitable" interest as a "springing use" which could not vest, if ever, "until all of the contingencies set up in the will" had been met. It is hardly surprising that a testamentary gift so beneficial to the community survived a contention that it violated public policy on dead-hand control of wealth. Nor is it surprising that the perpetuities problem was handled awkwardly and inconsistently. Though in the opinions much is made of the time at which an educational association might be formed, nothing more than generalized allusions are made to the time at which "all bequests herein shall have been paid." Does the explanation for differentiation lie in the fact that some "administration contingencies" (herein the appointment of the administrators of the educational association) are more likely than not to be resolved within the perpetuities period?

In Thomas v. Utterback ${ }^{87}$ the testatrix devised to each of her four children an interest in land for life and, in the words of the court, "at his ... death ... to any child or children he ... might leave surviving, for ... life ; . with remainder in fee" to the great-grandchildren ${ }^{88}$ of the testatrix per stirpes. The contention of a child of the testatrix that the will violated the Rule Against Perpetuities was disposed of by the Court of Appeals of Kentucky in two sentences: "[T]he only void provision ... was that her great-grandchildren should acquire the remainder in fee. The preceding life estates ... were valid." Apparently the court regarded as obvious both the characterization of the gift to unborn great-grandchildren as contingent and the reasons prompting such characterization..$^{89}$ Cases of this kind are some evidence that a group of interests classified under the traditional formulae as "contingent remainders" (above, in unborn great-grandchildren) is dying out in the perpetuities field through the

$$
87269 \text { S.W.2d } 251 \text { (Ky. App. 1954). }
$$

${ }^{88}$ The paraphrasing of the terms of the will by the court reads "remainder in fee simple to vest in the issue of her great-grandchildren per stirpes," but the description of the gift in fee at a later point in the opinion makes it clear that the beneficiaries were great-grandchildren.

${ }^{89} \mathrm{It}$ is impossible to determine from the opinion whether or not the rule in Cattlin v. Brown, 11 Hare 372, 68 Eng. Rep. 1318 (Ch. 1853), would save part of the gift to greatgrandchildren inasmuch as no reference is made to grandchildren of the testatrix in being at her death. 
process of inarticulate construction: that is, a court may unconsciously or haphazardly invalidate a gift without classifying interests. Whether courts have moved beyond the "vesting" test of validity can only be matter for conjecture.

\section{ConcLUSION}

If all grantors, settlors and testators were themselves expert draftsmen or employed expert draftsmen, there would be little litigation involving the validity of future interests under the Rule Against Perpetuities. Limitations would be stereotyped, standardized, and recognizable as falling within a particular category. Violations of the Rule would be rare, there being no insurmountable difficulties to confining gifts within permissible limits. -

Such idyllic conditions do not exist and are not likely to arise. The homemade will is a formidable document, and even the professionally prepared instrument may be offered for construction by the very lawyer who drew it. That being so, ambiguities in language must be resolved and disputes settled on the basis of such guides to rational decision as seem to exist.

The basic criticism of the categories of future interests presented by recognized authorities is not that they are vacuous but that (as Kales pointed out a half century ago), they are hardly worth the effort required to master them. Based as they are on a notion which lost all significance over four hundred years ago, rife with inconsistencies, they represent an excuse for decision rather than a reason. Furthermore, they are ideal types to which it is frequently almost impossible to assimilate the half-articulated expressions of the donor. At the very point at which a guide would prove most helpful, it is found wanting; alternatives are permissible and we are thereafter adrift. Even if assimilation to prototypes is possible, it is demonstrable that in perpetuities cases it is not indulged, or is indulged half-heartedly, or is indulged imperfectly. ${ }^{90}$

${ }^{90}$ In Victory Oil Co. v. Hancock Oil Co., 125 Cal. App. 2d 222, 270 P.2d 604 (1954), the grantors in 1922 deeded real property to one Tucker "excepting therefrom and reserving to the grantors ... all oil ... on or under the said described lands . . . provided however that the said grantees shall be entitled to one-half $\left(\frac{1}{2}\right)$ of all net royalty ... received by said grantors. ..." The deed further provided that in the event oil was not found within five years from the time of the grant, all rights of the grantors should cease and the grantee be vested with absolute title. In the event oil was found within five years from the time of the grant, "the rights of said grantors . . . shall continue for a period of twenty (20) years, and so long thereafter as oil . . . shall be produced. . .." Three wells sunk within the five years period produced until 1946. A fourth sunk in 1931 was still producing when the California courts were asked to determine whether the interest in oil reserved to the grantors andd ullimately passing to Tucker under the above described circunnstances was void under the Rule Against Perpetuities. The opinion of the California appellate court contains no explicit analysis of the future interest under consideration, and even the classification adopted is implicit. (Two paragraphs discuss the characteristics of contingent remainders.) The attempted grant to Tucker should be broken down as follows:

1) if oil is not found within five years, to Tucker.

2) if oil is found within five years and production ceases

a) within twenty years from the time of the grant, to Tucker at the end of twenty years from the time of the grant. 
Whether or not the "vesting" of interests for perpetuities purposes ever had a defensible content becomes an irrelevant inquiry once it becomes clear that in recent times the concept has lost nearly all content. It is small consolation to know that the "indefeasibly vested remainder" is almost always accorded the characteristics attributed to it by authoritative doctrine. It is the more tenuous interest that causes classification difficulties and it is the more tenuous interest that may succeed or fail without having been classified at all.

That modern courts in perpetuities cases are abandoning the categories of future interests is to a fair degree demonstrable. That they are assimilating functional equivalents can likewise be shown. But how they decide cases in the absence of classification is not at all clear. Occasionally they are openly influenced by the fact that events have occurred in the interval between the effective date of the instrument and the time litigation commences. ${ }^{\text {II }}$ Sometimes

b) within twenty years from the time oil is found, to Tucker at the end of twenty years from the time oil is found.

3) if oil is found within five years and production ceases at any time beyond the twenty year period (irrespective of when the twenty year period commences), to Tucker when production ceases.

Whatever the classification accorded the contingent interest, 1) and 2) a) above are good under the Rule as the future interest becomes possessory, if at all, within the period in gross of twenty-one years. 2) b) and 3) above are bad under the Rule because the future interest might become possessory beyond the period in gross. It is doubtful that a "remainder" classification is permissible under orthodox doctrine. If the interest reserved in the grantors be likened to a "determinable fee," the interest in Tucker is an executory interest. If the interest reserved in the grantors be likened to a "term," the interest in Tucker (being contingent) is an executory interest.

${ }^{91}$ In McQueen v. Branch Banking \& Trust Co., 234 N.C. 737, 68 S.E.2d 831 (1952), the testatrix, after providing for a sister, devised the rest of her property to another sister, Margaret, for life, then to the bank "in trust for the sole and specific uses . . . hereinafter set forth. ..." (Here followed gifts to named beneficiaries.) "The trust . . . shall continue for a period of twenty-five (25) years from the date of filing this . . will . . for probate . . or from the ... death of my sister, Margaret ... whichever may be the later date" and at that time the trustee was to pay over corpus to the named persons receiving income at that time. The limitation to the bank was characterized by the Supreme Court of North Carolina as a "remainder subject to the life estate of Margaret. ..." Legal title vested in the trustee immediately upon the death of the testatrix. An "administration contingency" construction was rejected. "... we are dealing with the situation as it is, not as it might have been. ... The will was promptly admitted to probate, and the date of the death of the life tenant marks the beginning of the twenty-five year period of the trust."

In Citizens Nat'l Bank v. St. Peters Lodge, 156 A.2d 768 (N.H. 1959), the testator created a trust of his residuary estate, the income to be paid out annually to designated persons during their lives "to be paid equaly [sic] to each one named, Mabel ... Sarah ... Susie ... and Frank. ... If Mabel . . . deceases before the length of time this is to run I direct her part of this income to be paid to Herbert ... her husband if alive. ... If Frank ... deceases before the length of time this is to run I direct his part of this income to be paid to his wife, Florence $\ldots$ if alive.... The Trustees to take out their pay for services annualy [sic]. Then all ballance [sic] remaining at the end of forty years, this is to run, I give one half to St. Peters Lodge.... if they are holding their Charter. The other half to the First Baptist Church. ... If St. Peters Lodge or the Church is out of existance [sic] then, or either one, so not to receive this money, I give their part to the Town of Bradford." Those beneficiaries who were natural persons having died (and the forty year period not having run), the trustee sought instructions 
they appear to be groping toward a possessory test of validity ${ }^{92}$ that has been suggested (not without reservations) by Simes. ${ }^{93}$ They seem to be affected (and naturally enough) by the probabilities in the particular case that events will

respecting disposition of corpus. To a suggestion by counsel that the gifts of corpus violated the Rule Against Perpetuities, the Supreme Court of New Hampshire answered as follows:

"The ... residuary clause ... bequeathed the income of the trust fund to the beneficiaries 'during their natural lives.' These gifts would terminate at the death of the beneficiaries or in forty years, at which time . . . the balance should go to the two named charities. However the will as a whole gives no indication that the testator considered a forty-year period in gross as a condition precedent to the right of the remaindermen to receive the balance of the fund. ... [T]he gift to the life beneficiaries was vested. [citation] The gift of the remainder to the charities was likewise a vested gift although the enjoyment thereof was postponed until the death of the last named life beneficiary or a period of forty years. [citation]."

The opinion of the court fails to take into account that the existence of the lodge at the termination of the life interests or the forty year period was essential to its qualifying for the gift of corpus. If "contingent" has definable content, that gift was a contingent gift which had in fact "rested" when the trustee sought instructions. However, see the rule of Edwards v. Hammond, 3 Lev. 132, 83 Eng. Rep. 614 (1683).

${ }^{2}$ See, for example, the opinion in In re Throm's Estate, $378 \mathrm{~Pa} .163,106$ A.2d 815 (1954). The testator, survived by his widow and his daughter Ruth, directed his trustee to pay income from a part of his residuary estate to Ruth for life and after her death to her issue until the death of the widow, and in default of issue, to the widow for life. The following clause disposing of corpus caused dispute: "At and upon the death of my wife ... and my daughter Ruth ... dying leaving lawful issue or issue of a deceased child or children, I order . . . my . . . Trustee to pay and deliver the whole net proceeds ... to the issue or issue of such lawful child or children of my daughter Ruth ... upon arriving at the age of thirty (30) years respectively. ..." The executor of Ruth (who died about two years before the widow) contended that the gift of corpus violated the Rule and that an intestacy resulted. The executor of Charles, son of Ruth, who survived both Ruth and the widow, contended that the gift was good. The Supreme Court of Pennsylvania approached the perpetuities problem by stating initially that under the Rule "the limit for the creation of an executory interest to commence was, under the common law" a life or lives in being and twenty-one years. [Emphasis supplied.] Then, by implication, the court recognized a condition of survivorship: "there would have been no question but that upon the death of his mother and grandmother ... Charles ... would have inherited a vested estate in remainder." At a later point the implication of survivorship is made express: "We agree ... that when testator gave the remainder, upon the death of his daughter, to her 'issue or issue of such lawful child or children' he must have meant that issue which sutrvived her." However, rejection of the "divide and pay over rule" seemed to require re-emphasis of the notion that possession was not deferred for too long a time: "There is an additional reason indicating that testator intended the remainder to be vested and not contingent. He provided that in case of the failure of any disposition, the bequest should pass to his widow, daughter and sister. It would indeed be strange if testator intended a contingent gift to issue and their descendants ad infinitum when they arrived at the age of thirty years when, in default of such contingency, the fund would pass to individuals who were living at the date of testator's death." Despite the court's allusion to executory interests, the opinion, on balance, seems to say this: the gift of corpus was a remainder contingent on surviving Ruth but not contingent on attaining thirty. The remainder "vested" at the end of lives in being (the widow and Ruth) at the death of the testator and the requirements of the Rule were satisfied. The opinion fails to indicate clearly that the remainder "vested" at the death of Ruth (there being little evidence that issue of Ruth were required to survive the widow).

${ }^{93}$ Sames, Public Policy and the Dead Hand 80 (1955). Schuyler sets out a detailed proposal in Schuyler, Should the Rule Against Perpetuities Discard Its Vest?, 56 MICH. L. REv. 683,887 (1958). "It seems that in the ideal system of law ... no interests which did not vest in possession within the allotted period would be allowed." GRAX $\$ 972$ 
take a reasonably predictable turn. To the extent. that the last-mentioned practice is indulged, not only is the traditional "possibilities" test of validity under the Rule abandoned, but also the "actualities" test is, by implication, rejected.

It is conventional in legal education to speak of the time-lag in the law, the implication frequently being that judges and legislators fail to see the need for reform so visible to the scholar and to the man in the street. Whatever validity the conventional notion may have in other contexts, it is clear that it has little relevance to the reformation of the law of future interests. Applying the Rule Against Perpetuities as stated by Gray presupposes a classification of limitations which frequently does not obtain in modern cases. The classic formulation of the Rule is invoked only as a formality; the actual decision rests on considerations left largely conjectural. Whether the cause be ignorance, indifference, or disdain, reformation of the Rule is proceeding apace in the courts, and the courts have been at least abreast of the scholars in this respect, if indeed not ahead of them. If recent cases reliably reflect the law, indefensible distinctions enshrined in texts will be taught in the classroom long after the assimilation of future interests not readily distinguishable has been accomplished in the courtroom. Pretty much unaided, judges are fashioning a Rule Against Perpetuities suited to the needs of the twentieth century. It awaits development and description. 